\title{
Comprehensive Management of Helicobacter pylori Infection
}

\author{
Abdul Ghaffar Hamzah*, Achmad Fauzi** \\ *Faculty of Medicine, Universitas Indonesia/Dr. Cipto Mangunkusumo General National Hospital, Jakarta \\ **Division of Gastroenterology, Department of Internal Medicine, Faculty of Medicine \\ Universitas Indonesia/Dr. Cipto Mangunkusumo General National Hospital, Jakarta
}

\section{Corresponding author:}

Achmad Fauzi. Division of Gastroenterology, Department Internal Medicine, Dr. Cipto Mangunkusumo General National Hospital. Jl. Diponegoro No. 71 Jakarta Indonesia. Phone: +62-21-3153957; Facsimile: +62-213142454.Email: prof.marcellus.s@gmail.com.

\begin{abstract}
Helicobacter pylori (Hp) infection is a chronic gram-negative bacterial infection, that infects the epithelium of the stomach. This prevalence is very high and varies depending on factors such as geographical location, ethnicity, age, and socioeconomic. The key management of Hp infection is accurate diagnosis and treatment. The H. pylori diagnostic examination consists of non-invasive and invasive tests, the most common non-invasive tests are serological tests, urea breath tests (UBT), and stool antigen tests, while invasive tests are rapid urease tests, histopathology, culture, and PCR. The goal of H. pylori eradication is to heal peptic ulcers and reduce the risk of gastric cancer. Eradication therapy that is recommended worldwide and used in Indonesia is the triple drug combination therapy consisting of a PPI, clarithromycin and amoxicillin or metronidazole for 14 days. The success of eradication therapy is highly dependent on the choice of therapeutic regimen, patient compliance in taking multi-drugs with possible drug side effects, and the sensitivity of H. pylori strains to the antibiotics consumed.
\end{abstract}

Keywords: Helicobacter pylori infection, risk factors, diagnostic test, management,

\begin{abstract}
ABSTRAK
Infeksi Helicobacter pylori (Hp) adalah infeksi bakteri gram negatif kronis yang menginfeksi epitel gaster. Prevalensi infeksi ini sangat tinggi dan bervariasi tergantung pada faktor-faktor seperti lokasi geografis, etnis, usia, dan sosial ekonomi. Kunci penatalaksanaan infeksi Hp adalah diagnosis dan pengobatan yang akurat. Pemeriksaan diagnostik $H$. pylori terdiri dari uji non-invasif dan invasif, uji non-invasif yang paling umum adalah tes serologis, urea breath test (UBT), dan tes antigen feses, sedangkan tes invasif adalah tes urease cepat, histopatologi, kultur, dan PCR. Tujuan pemberantasan H. pylori adalah untuk menyembuhkan tukak lambung dan mengurangi risiko kanker lambung. Terapi eradikasi yang direkomendasikan di seluruh dunia dan digunakan di Indonesia adalah terapi kombinasi tiga obat yang terdiri dari PPI, klaritromisin dan amoksisilin atau metronidazol selama 14 hari. Keberhasilan terapi eradikasi sangat tergantung pada pilihan regimen terapi, kepatuhan pasien dalam meminum kombinasj obat dengan kemungkinan efek samping obat, dan sensitivitas strain H. pylori terhadap antibiotik yang dikonsumsi.
\end{abstract}

Kata kunci: infeksi Helicobacter pylori, faktor risiko, uji diagnosis, manajemen 


\section{INTRODUCTION}

Helicobacter pylori $(\mathrm{Hp})$ is a gram-negative bacterium that primarily infects the gastric epithelium. $\mathrm{Hp}$ infection is a major public health problem that has long been a concern because of the high incidence in the community. The prevalence of $\mathrm{Hp}$ infection was found to be quite high in both developed and developing countries, reaching more than $50 \%$. Especially in developing countries, this high prevalence is also still faced with difficulties in establishing a definite diagnosis of Hp infection due to the availability of adequate examination tools. ${ }^{1,2}$

H. pylori bacteria were first discovered by Marshall and Warren in 1983. Along with the development of diagnostic tools, Hp infection has become one of the most common causes of dyspepsia and gastrointestinal problems in various parts of the world since then. These infections are found in various populations, ranging from children to adults, and from various sociodemographic backgrounds.

Handling Hp infection requires a comprehensive understanding starting from the pathophysiology and pathogenesis of bacterial infection to cause disease, factors that can increase the risk of people infected by $\mathrm{Hp}$, examination methods to establish an accurate diagnosis, and therapeutic approaches. Because the treatment duration is quite long, clinicians must be able to firmly diagnose $\mathrm{Hp}$ and provide appropriate treatment, so that the cure rate will be high and avoid various long-term consequences, such as the occurrence of gastrointestinal malignancies and ulcers in the gastrointestinal tract. This review article will discuss $\mathrm{H}$ pylori infection comprehensively. ${ }^{1,2}$

\section{EPIDEMIOLOGY OF H. PYLORI}

\section{H. Pylori Epidemiology}

Difference in H. pylori (Hp) strain is associated to its virulence factors. Host and environmental factors also had an important role in $H$ pylori infection, such as age, ethnicity, gender, geographic, and socioeconomic status. The main reason of higher prevalenve among developing countries was that Hp infection mainly transmitted through oral-oral or faecal-oral routes. Sanitation factors such as consumable water, foods, and population density are among factors affect $\mathrm{Hp}$ infection. ${ }^{1,2}$

Hp prevalence globally reach $50 \%$, about $30-40 \%$ in developed countries and $80-90 \%$ in developing countries. Among them, $10-20 \%$ had a risk to develop gastroduodenal diseases. In Indonesia, Hp prevalence is around $36-46 \%$ with the youngest cases found in 5 months old patient. Based on study in 5 big cities in Indonesia (2014-2015), from 267 patient with dyspepsia, the prevalence of $\mathrm{Hp}$ is $22.1 \%(59 / 267){ }^{1-4}$

\section{RISK FACTORS}

\section{Demographic and Sosioeconomic Factors}

A study by Genta, et al that analyze demographic and socioeconomic factors among 487.587 american that underwent upper gastrointestinal endoscopy with biopsy reported that education and income level were correlated to lower prevalence of $\mathrm{Hp}$, gastric atrophy, and GI malignancy. ${ }^{5}$ Another study by Wen, et al that compared Hp infection prevalence in rural area (Shexian) and urban area (Shijiazhuang) reported higher Hp prevalence in rural area (75\% vs. $50 \%) .{ }^{5}$

\section{Dietary factors}

In a cross-sectional study of 166 adults in Portugal, the highest prevalence of $H$. pylori infection occurred in a population that consumed less vegetables and fruits and consumed more processed foods. Meanwhile, infrequent hand hygene and consumption of water from weel are other factors that increase the risk of $H$. pylori infection. Other data showed that there is no significant relationship between $H$. pylori infection and alcohol, coffee, nor tobacco consumption. ${ }^{5}$

\section{Drinking Water Source Factors}

Based on a study in Peru, H. pylori DNA can be identified from drinking water samples; $20.3 \%$ of drinking water samples were contaminated. A higher temperature related to the greater quantity of $\mathrm{H}$ pylori bacteria. Based on a prospective study conducted by Syam et al on 5 Islands in Indonesia, in 2014-2015, populations who use tap water as drinking water source had a lower incidence of $H$ pylori infection compared to populations who used river or well for water source $(\mathrm{OR}=9.67 ; \mathrm{p}: 0.03)^{4,5}$

\section{Race and Ethnicity Factors}

In North America, the prevalence of $H$ pylori infection varies with socioeconomic status and race/ethnicity. In general, prevalence was lower among non-Hispanic whites compared to other racial/ethnic groups, including Africa-American, Hispanic-American, Native-American, and Alaskan 
Native. A higher proportion of African ancestry was reported to have a higher rate of $H$ pylori infection, suggesting that race/genetic factors may have some role in the predisposition to infection - not related to socioeconomic factors. ${ }^{4,5}$

Based on a prospective study conducted by Syam et al in 5 Islands in Indonesia (Sumatra, Java, Borneo, Sulawesi, and Papua), in 2014-2015, it showed that several ethnic: Papua, Batak, and Bugis had a higher risk of infection with $H$. pylori compared to Javanese, Dayak, and Chinese $(\mathrm{OR}=30.57,6.31,4.95 ; \mathrm{OR}=$ 28.39, 5.81, 4.61 and $\mathrm{OR}=23.23,4.76,3.77$; $\mathrm{p}<0.05$ ). Protestants had a higher risk of $H$. pylori infection than Catholics $(\mathrm{OR}=4.42 ; \mathrm{p}=0.008)$, and the population aged 50-59 years old had a higher risk of $H$ pylori infection than the population aged 30-39 years old $(\mathrm{OR}=2.98, \mathrm{p}: 0.05)^{4.5}$

\section{PATOPHYSIOLOGY OF GASTRITIC DUE TO $\boldsymbol{H}$. PYLORI}

H. pylori bacteria have an ability to enter mucus, adhere to gastric epithelial cells, evade immune responses, resulting in colonization and persistent transmission. After entering the digestive tract, $H$. pylori bacteria produce urease. Urease hydrolyzes urea into carbon dioxide and ammonia, so that $H$. pylori can survive in an acidic environment. The activity of this enzyme is regulated by a $\mathrm{pH}$-gated urea channel, Ure-I, which opens at low $\mathrm{pH}$ and closes urea flow in neutral conditions. Bacterial motility is very important in colonization, and the H. pylori flagellum is very well adapted to the structure of stomach folds. ${ }^{1,6,7}$

Most of H. pylori secrete an exotoxin, VacA (vacuolating cytotoxin), that enters the cell membrane and attacks the mitochondrial membrane, causing the release of cytochrome $\mathrm{c}$ and apoptosis process. The pathogenic role of these toxins is still debated. Some $H$. pylori strains have cag-PAI (cag pathogenicity island), a genomic fragment containing 29 genes. Some of these genes are components that help translocate CagA into host cells. H. pylori causes persistent inflammation of the stomach. This inflammatory response begins with initial neutrophil withdrawal, followed by $\mathrm{T}$ and B lymphocytes, plasma cells, and macrophages, along with epithelial cell damage. H. pylori infection stimulates mucosal and systemic humoral responses. The production of antibodies can not eliminate/eradicate the infection, and even cause tissue damage. In some patients infected with $H$. pylori, an autoantibody response to $\mathrm{H}+/ \mathrm{K}+$-ATPase of gastric parietal cells is associated with increased gastric corpus atrophy. ${ }^{1,6,7}$

\section{VIRULENCE FACTORS OF HELICOBACTER PYLORI}

Different virulence factors in $H$ pylori contribute to different clinical outcomes and prognosis. Several virulence factors that play an important role are: (1) the ability of bacteria to avoid gastric acid which is influenced by urease, bacterial shape, and flagella; (2)

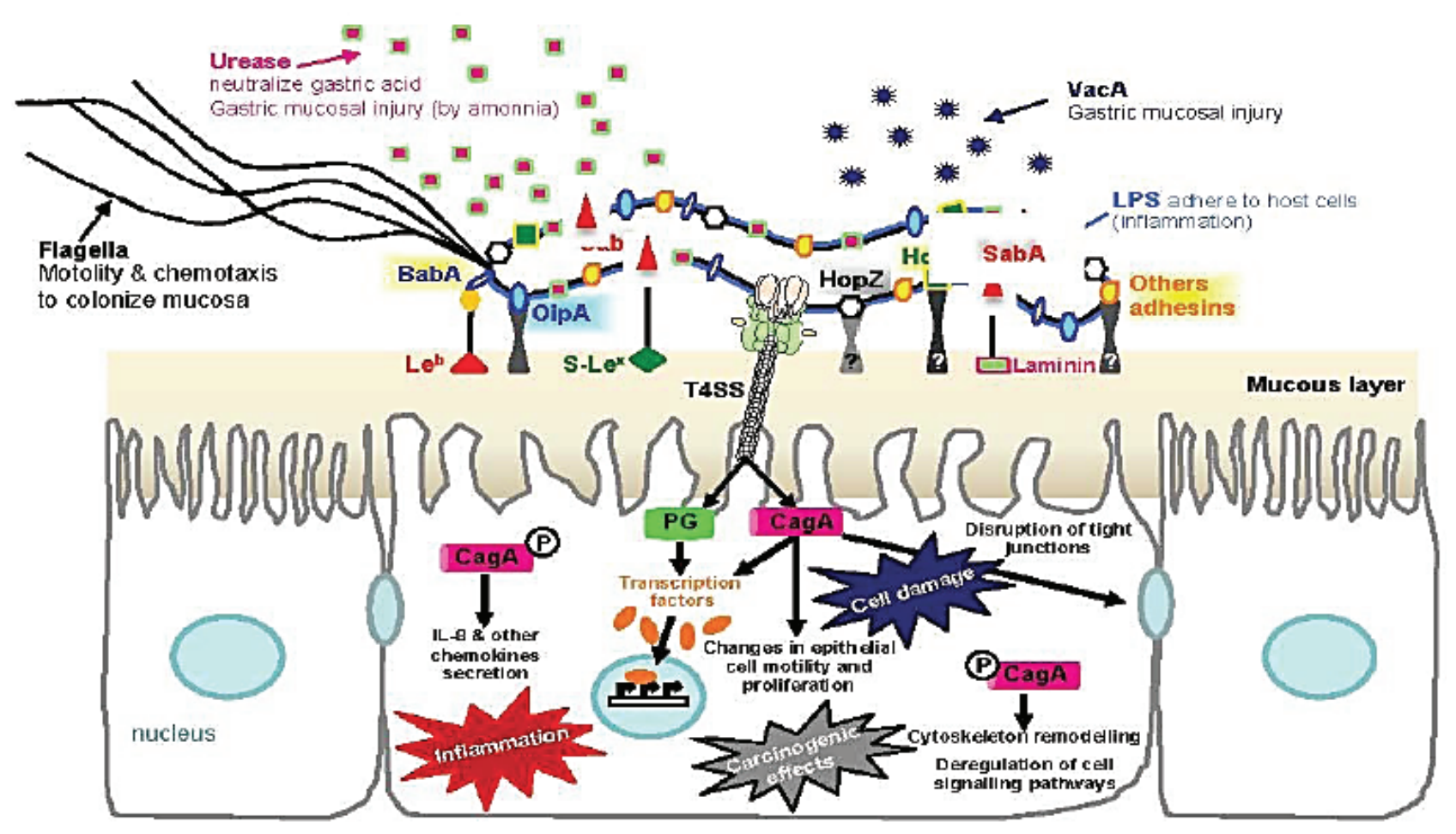

Figure 1. Pathogenesis of Helycobacter pylori infection ${ }^{7}$ 
colonization factor against epithelial cells mediated by BabA, SabA, OipA, and HopQ; (3) pathogenic factors against epithelial cells mediated by cagA, VacA, cagPAI, CagT, CagY, Cag , CagL, HtrA, outer membrane vesicles, and $\gamma$-glutamyl transpeptidase. An in vitro study states that $\mathrm{H}$. pylori bacteria that produce CagA, VacA, and OipA proteins simultaneously tend to show more severe inflammatory activity that contributes to the development of gastric cancer. ${ }^{14,15}$

\section{DIAGNOSISANDTREATMENTOF HELICOBACTER PYLORI}

\section{Diagnosis of Helicobacter pylori Infection}

The purpose of diagnostic testing for $H$ pylori infection is to establish the diagnosis of infection before administering treatment and also for epidemiological research. Another purposes is to observe whether the eradication has been achieved after administration of antibiotics. The indications for testing for $\mathrm{H}$ pylori infection are based on the ACG Clinical guidelines: all patients with active peptic ulcer disease (PUD), a history of PUD (unless previously recovered from $H$ pylori infection and documented), lymphoma associated with low grade lymphoid tissue and gastric mucosa (MALT), or a history of endoscopic gastric cancer resection. Those who tested positive should be treated for infection. In patients with uninvestigated dyspepsia under 60 years of age and without any alarm symptoms, consideration are non-endoscopic examination for $H$ pylori infection. Those who tested positive should received eradication therapy. Examination among patients with gastroesophageal reflux disease (GERD) is not recommended unless the patient has a history of peptic ulcer or dyspepsia. The ACG also recommends screening in patients on long-term NSAID treatment, unexplained iron deficiency anemia, and adult ITP patients, but this recommendation is based on poor quality evidence. ${ }^{1,8,9}$

The H. Pylori diagnostic examination consists of non-invasive and invasive tests. The most common non-invasive tests are serological tests, urea breath tests (UBT), and stool antigen tests, while invasive tests are rapid urease tests, histopathology, tissue culture, and PCR. One of these tests is used to diagnose $H$ pylori infection before and after eradication therapy. UBT and $H$ pylori stool antigen assay using monoclonal antibodies are useful for eradication assessment. After effective eradication, UBT control is generally used after antibiotics regiment for one month and proton pump inhibitors for 7-14 days. If UBT is not available, a stool antigen test may be performed. ${ }^{4,8-10}$

\section{Non-invasive Test}

\section{Urea Breath Test (UBT)}

This is the gold standard for non-invasive detection of H pylori infection, which was first proposed in 1987 by Graham and Bell. Urea labeled $13 \mathrm{C}$ is given in oral administration. If $H$. pylori is present in the stomach, its urease activity decomposes the urea label into $13 \mathrm{CO} 2$ and ammonia. $13 \mathrm{CO} 2$ enters the blood from the gastrointestinal tract and is excreted during expiration. The rate of increase of $13 \mathrm{C}$ carbon dioxide during expiration was measured. The use of 13C-urea filmcoated tablets reduces the effect of urease-producing bacteria in the oral cavity, thereby increasing diagnostic accuracy. It is considered positive if there is an increase of at least $0.01 \%$ of isotope levels compared to the sample of breathing air before giving 75-100 $\mathrm{mg}$ of urea. It use mass spectrometer which is very sensitive, but expensive. False negative results can occur if the patient is receiving antibiotics, antacids, bismuth, or anti-acid secretions. So it is recommended that the drugs mentioned earlier to be discontinued 2 weeks before the test is carried out. Diagnostic accuracy: $98 \%$ sensitivity and $98 \%$ specificity. ${ }^{1,2,8,11}$

\section{Serological Test}

Serological tests are widely used in epidemiological research because they are relatively inexpensive and acceptable to asymptomatic patients or children who do not want to be examined by invasive methods such as gastroscopy. In general, serologic test evaluate IgG antibodies against Helicobacter pylori. Several technique used are ELISA, Westernblot, complement fixation, and immunofluorescence. In Indonesia, ELISA technique is widely available, relatively simple and the results are accurate. To increase the sensitivity and specificity, a cut off point is used as the limit of positive and negative results in a population. Research in Jakarta shows that setting a cut off point of 1800 $\mathrm{EU} / \mathrm{L}$ can increase the sensitivity of the ELISA test. ${ }^{1,2,8}$

\section{Stool Antigen Test}

This method used for the direct detection of $H$ pylori-derived antigens excreted in the feces. The kits that currently available use monoclonal antibodies with both high sensitivity and specificity. This assay is recommended in European guidelines as the test to 
evaluate eradication. Although H. pylori in the coccoid form gave a negative UBT result, antigenicity was still detected in this assay. This method also shows excellent diagnostic accuracy. ${ }^{8,11}$

\section{Invasive Test}

\section{Rapid Urease Test}

The rapid urease test is a quick, simple, and accurate method for identifying $H$. pylori. However, the sensitivity after eradication is highly variable. In the rapid urease test, it is desirable to collect biopsy tissue for histology at the same time. Due to the high specificity, samples tested positive by the rapid urease method can be concluded as positive for H. pylori infection. When sodium bicarbonate (alkali) is used in the treatment to remove gastric mucus, the sample should be wiped to avoid false positive results due to the effect of sodium bicarbonate. Diagnostic accuracy: Pre-eradication sensitivity is around $91.0-98.5 \%$ and specificity is $90.9-100 \%$. Post-eradication sensitivity was $58.8-86 \%$ and specificity was $97.8-99.2 \% .{ }^{1,8,11}$

\section{Histologic Examination}

Histological methods for detecting H pylori have a high capacity and can be combined with histological diagnosis. An example of combination examination is combining stains such as Giemsa staining with hematoxylin eosin $(\mathrm{H} \& \mathrm{E})$ staining. Immunostaining is useful for distinguishing $H$. pylori and other bacteria when small numbers of bacteria are present and when the bacteria are in the coccoid form, among other cases, where assessment is difficult by non-specific staining. When patients take PPIs, H. pylori can change to a coccoid form and migrate to the deeper parts of the gastric foveola. Furthermore, aberrant parietal cells can be observed in the intracellular canaliculi. Diagnostic accuracy in pre-eradication using H\&E staining: sensitivity is $92-98.8 \%$ and specificity is $89-100 \%$. $^{1,8,11}$

\section{Microbiological Culture}

The presence of $H$ pylori can only be confirmed directly by culture. This method has excellent specificity and allows for preservation, and further testing of antimicrobial resistance profile. Resistance to antibacterial agents is desirable to be tested, whenever possible. Although the agar dissolution method is recommended for drug resistance tests to determine the minimal inhibitory concentration, other methods (eg E test and broth microdilution) are also used. To obtain the bacterial strain, a single colony of H. pylori was cultured by immersion in a brain heart infusion (BHI) 1-2 $\mathrm{mL}$ and purified cultures were subsequently performed on blood agar medium. The collected bacterial cells were put into a BHI broth containing $15 \%$ glycerin, after confirming that the cells were not in the coccoid form, and then stored freeze. Diagnostic accuracy: sensitivity 68\%-98\% and specificity $100 \%{ }^{1,8,11}$

\section{Polymerase Chain Reaction (PCR)}

Polymerase chain reaction is an attractive option because of its high sensitivity (94-100\%) and high specificity (100\%). The materials used are biopsy specimens, both had been paraffinized or formerly used for urease tests (such as CLO). Its advantage is its ability to detect low density infections, even the expression of various bacterial genes such as Cag.A. In addition, other sample that can be used is gastric fluid, but care must be taken to avoid contamination from either the endoscope scope or from the oral cavity or dental plaque because it can give false positive results. PCR can also be used to evaluate eradication therapy. This method is sophisticated but with a fairly expensive cost. ${ }^{1}$

\section{HELYCOBACTER PYLORI ERADICATION}

The goal of $H$. pylori eradication is to heal peptic ulcers and reduce the risk of gastric cancer. There are sources said that when cancer precursor lesions have formed on the gastric mucosa, eradication therapy to prevent gastric cancer is no longer effective. $H$. pylori eradication therapy is supported by consensus that is used worldwide that proven to be safe and effective. The standard regimen consists of several drug combinations. Vaccines are currently not available and the source of the $H$. pylori bacteria is not known yet, so it becomes difficult recomending to avoid this infection. ${ }^{2}$

\section{Treatment Regiments for $\boldsymbol{H}$. pylori Eradication}

Before eradication therapy is started, what should be asked is the history of previous antibiotic use (conditional recommendation, moderate quality of evidence). Based on ACG recommendations, the use of three-drug combination therapy consisting of a PPI (omeprazole $2 \times 20 \mathrm{mg}$, lansoprazole $2 \times 30 \mathrm{mg}$, esomeprazole $2 \times 20 \mathrm{mg})$, clarithromycin ( $2 \times 500$ $\mathrm{mg})$, and amoxicillin $(2 \times 1000 \mathrm{mg})$ or metronidazole $(3 \times 500 \mathrm{mg})$ for 14 days. Table 1 shows the first-line, 


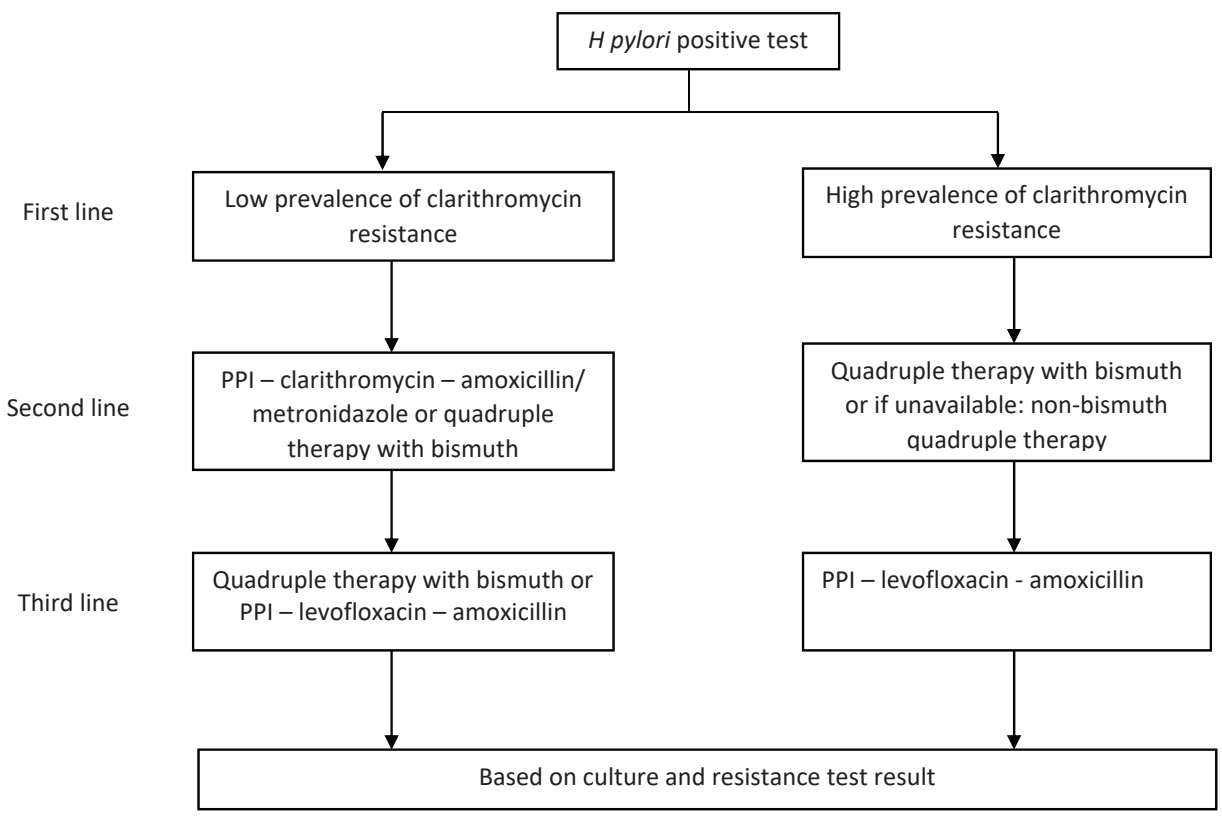

Figure 2. Algorithm in $H$ pylori eradication ${ }^{12}$

second-line, and third-line treatment regimens for $H$ pylori eradication. Treatment with clarithromycin should be avoided if the level of drug resistance in an area is $>15 \%$, and in patients with a history of macrolide drug use. Quadruple therapy with Bismuth and PPI, clarithromycin, amoxicillin or metronidazole for 10-14 days, is the best option in patients with a history of macrolide drug use and penicillin allergy. Based on a prospective study by Syam et al in 2010, Hp eradication therapy with triple therapy (rabeprazole, amoxicillin, and clarithromycin) for 7 days was better than therapy for 5 days. ${ }^{8,9,12}$

\section{Factors of Successful Therapy and Resistance}

The success of eradication therapy is highly dependent on the choice of therapeutic regimen, patient compliance in taking multi-drugs with possible drug side effects, and the sensitivity of H. pylori strains to the antibiotics received. The incidence of drug resistance against $H$. pylori eradication in the United States in 2009-2011, the highest was levofloxacin (31\%), metronidazole $(20 \%)$, and clarithromycin $(16 \%)$, while in Indonesia the most resistance occurred to metronidazole (46.7\%), levofloxacin (31.2\%), amoxicillin (5.2\%), and tetracycline $(2.6 \%)$. Examinations to evaluate the success of eradication therapy are carried out with UBT, stool antigen test, or a biopsy at least 4 weeks after completion of antibiotic therapy and 1-2 weeks after completion of PPI treatment. ${ }^{8,11,13}$
Table 1. Treatment regiments for H.pylori eradication ${ }^{12}$

\begin{tabular}{|c|c|c|}
\hline Drugs & Dosage & Duration \\
\hline \multicolumn{3}{|l|}{$1^{\text {st }}$ line } \\
\hline PPI* & $2 \times 1$ & \multirow[t]{3}{*}{ 7-14 days } \\
\hline Amoxicillin & $1000 \mathrm{mg}(2 \times 1)$ & \\
\hline Clarithromycin & $500 \mathrm{mg}(2 \times 1)$ & \\
\hline \multicolumn{3}{|c|}{ In area with clarithromycin resistance $>20 \%$} \\
\hline PPI* & $2 \times 1$ & \multirow[t]{4}{*}{ 7-14 days } \\
\hline Bismut subsalicylate & $2 \times 2$ tablet & \\
\hline Metronidazole & $500 \mathrm{mg}(3 \times 1)$ & \\
\hline Tetracycline & $500 \mathrm{mg}(4 \times 1)$ & \\
\hline \multicolumn{3}{|l|}{ If Bismuth not available: } \\
\hline $\mathrm{PPI}^{*}$ & $2 \times 1$ & \multirow[t]{4}{*}{ 7-14 days } \\
\hline Amoxicillin & $1000 \mathrm{mg}(2 \times 1)$ & \\
\hline Clarithromycin & $500 \mathrm{mg}(2 \times 1)$ & \\
\hline Metronidazole & $500 \mathrm{mg}(3 \times 1)$ & \\
\hline \multicolumn{3}{|c|}{$\begin{array}{l}2^{\text {nd }} \text { line: this regiment can be used if treatment failed using } \\
\text { clarithromycin-based regiment. }\end{array}$} \\
\hline PPI* & $2 \times 1$ & \multirow[t]{4}{*}{ 7-14 days } \\
\hline Bismut subsalicylate & $2 \times 2$ tablet & \\
\hline Metronidazole & $500 \mathrm{mg}(3 \times 1)$ & \\
\hline Tetracycline & $250 \mathrm{mg}(4 \times 1)$ & \\
\hline $\mathrm{PPI}^{*}$ & $2 \times 1$ & \multirow[t]{3}{*}{ 7-14 days } \\
\hline Amoxicillin & $1000 \mathrm{mg}(2 \times 1)$ & \\
\hline Levofloxacin & $500 \mathrm{mg}(2 \times 1)$ & \\
\hline \multicolumn{3}{|c|}{$\begin{array}{l}3^{\text {rd }} \text { line: if treatment failed using } 2^{\text {nd }} \text { line. If possible, choice is based on } \\
\text { antimicrobial resistance test/ clinical condition. }\end{array}$} \\
\hline $\mathrm{PPI}^{*}$ & $2 \times 1$ & \multirow[t]{3}{*}{ 7-14 days } \\
\hline Amoxicillin & $1000 \mathrm{mg}(2 \times 1)$ & \\
\hline Levofloxacin & $500 \mathrm{mg}(2 \times 1)$ & \\
\hline \multicolumn{3}{|c|}{$\begin{array}{l}\text { *PPIs used include rabeprazole } 20 \mathrm{mg} \text {, lansoprazole } 30 \mathrm{mg} \text {, omeprazole } 20 \\
\mathrm{mg} \text {, pantoprazole } 40 \mathrm{mg} \text {, esomeprazole } 40 \mathrm{mg} \text {. Note: Sequential therapy } \\
\text { (may be given as first line if there is no data on clarithromycin resistance): PPI } \\
\text { + amoxicillin for } 5 \text { days followed by PPI + clarithromycin and nitroimidazole } \\
\text { (tinidazole) for } 5 \text { days. }\end{array}$} \\
\hline
\end{tabular}

\section{CONCLUSION}

Helicobacter pylori $(\mathrm{Hp})$ infection is a chronic gram-negative bacterial infection, that infects the epithelium of the stomach. This prevalence is very high and varies depending on factors such as geographical location, ethnicity, age, and socioeconomic. In 
Indonesia the overall prevalence of $H$ pylori infection is $22.1 \%$. The population aged $50-59$ years was more infected with $H$ pylori than the population aged 3039. The purpose of diagnostic testing for $\mathrm{H}$ pylori infection is to establish the presence of infection before administering treatment or for epidemiological research. The H pylori diagnostic examination consists of non-invasive and invasive tests, the most common non-invasive tests are serological tests, urea breath tests (UBT), and stool antigen tests, while invasive tests are rapid urease tests, histopathology, culture, and PCR.

The goal of $H$. pylori eradication is to heal peptic ulcers and reduce the risk of gastric cancer. Eradication therapy that is recommended worldwide and used in Indonesia is the triple drug combination therapy consisting of a PPI, clarithromycin and amoxicillin or metronidazole for 14 days. The success of eradication therapy is highly dependent on the choice of therapeutic regimen, patient compliance in taking multi-drugs with possible drug side effects, and the sensitivity of $H$. pylori strains to the antibiotics consumed.

\section{REFERENCES}

1. Rani, AA. Fauzi A. Infeksi Helicobacter pylori dan Penyakit Gastro-duodenal. In: Sudoyo, A W. Setiyohadi, B. Alwi, I. Simadibrata, M. Setiati S, eds. Buku Ajar Ilmu Penyakit Dalam. Edisi V. Jakarta: Interna Publ 2016.p.501-8.

2. Hunt RH, France FM. Helicobacter pylori in Developing Countries . World Gastroenterology Organisation Global Guideline.

3. Hooi JKY, Lai WY, Ng WK, Suen MM, Underwood FE, Tanyingoh D, et al. Global prevalence of Helicobacter pylori infection: systematic review and meta-analysis. Gastroenterology 2017;153:420-9.

4. Syam AF, Miftahussurur M, Makmun D. Risk factors and prevalence of Helicobacter pylori in five largest islands of Indonesia: a preliminary study. PLoS One 2015;10:1-14.

5. Sjomina O, Pavlova J, Niv Y, Leja M. Epidemiology of Helicobacter pylori infection. Helicobacter 2018;23:6-11.

6. Waskito LA, Salama NR, Yamaoka Y. Pathogenesis of Helicobacter pylori infection. Helicobacter 2018;23:1-6.

7. Oleastro M, Ménard A. The role of Helicobacter pylori outer membrane proteins in adherence and pathogenesis. Biology 2013;2:1110-34.

8. Chey WD, Leontiadis GI, Howden CW, Moss SF. CME ACG clinical guideline : treatment of Helicobacter pylori infection. Am J Gastroenterol 2017;112:212-39.

9. American Family Physician E. Practice Guidelines $H$ pylori infection : ACG Updates Treatment Recommendations. AAFP 2018;97:135-137.

10. Kaplan M, Tanoglu A, Duzenli T TA. Helicobacter pylori treatment in Turkey: Current status and rational treatment options. North Clin Istanb 2020;7:87-94.

11. Kato M, Ota H, Okuda M, Kikuchi S, Satoh K, Shimoyama T. Guidelines for the management of Helicobacter pylori infection in Japan: 2016 Revised Edition. Helicobacter 2019;24:1-17.
12. Nasional Konsensus. Penatalaksanaan Dispepsia dan Infeksi Helicobacter pylori. (In: Simadibrata K, Marcellus; Makmun, Dadang; Abdullah, Murdani; Syam, Ari Fahrial; Renaldi, Kaka; Fauzi, Ahmad; Maulahela, Hasan; Utari AP, eds). Jakarta: PGI dan KSHPI:2014.

13. Miftahussurur M, Syam AF, Nusi IA, Makmun D, Waskito LA, Zein LH, et al. Surveillance of Helicobacter pylori antibiotic susceptibility in Indonesia: different resistance types among regions and with Novel genetic mutations. PLoS One 2016:11:e0166199.

14. Ansari S, Yamaoka Y. Helicobacter pylori virulence factors exploiting gastric colonization and its pathogenicity. Toxins 2019;11:677.

15 Yamako, yoshio; Graham, David Y. Helicobacter pylori virulence and cancer pathogenesis. Future Oncol 2014;10:14871500 . 